\title{
Environmental influences on fish assemblage distribution of an estuarine coastal lagoon, Ria de Aveiro (Portugal)*
}

\author{
LÚCIA POMBO $^{1}$, MICHAEL ELLIOTT $^{2}$ and JOSÉ EDUARDO REBELO ${ }^{1}$ \\ ${ }^{1}$ University of Aveiro, Department of Biology, 3810-193 Aveiro, Portugal. E-mail: LPombo@bio.ua.pt \\ ${ }^{2}$ University of Hull, Cottingham Road, Hull, HU6 7RX, UK.
}

\begin{abstract}
SUMMARY: Fish assemblage was examined for patterns in spatial and seasonal structure within an estuarine coastal lagoon, Ria de Aveiro. Two years of variation in abiotic conditions were recorded to identify factors responsible for maintaining the structure of fish assemblages. Nine sites were sampled monthly with a traditional "chincha" beach-seine net between November 1998 and October 2000. Fish abundance and biomass changed significantly between sites. Temperature was found to be the most important abiotic factor affecting the abundance (number of fish) distribution of fish assemblage, which is more related to seasonal migrations than to spatial migrations. Salinity was the most important abiotic factor affecting the fish biomass, with temperature also having a major influence. The other abiotic parameters analysed also showed some influence on the distribution of fish, although, isolated from the other controlled and/or uncontrolled factors, they could not fully explain all the differences between assemblages. Feeding analysis indicates that fish assemblage is mostly dependent on small benthic and pelagic crustaceans and/or detritus, although they can feed opportunistically on other prey. The low spatial segregation of fish in relation to feeding preference indicates that, in a food-rich lagoon such as Ria de Aveiro, the environmental-biological interactions appear to have a greater effect on fish distribution than do biological interactions.
\end{abstract}

Key words: fish fauna, diversity, environmental factors, Ria de Aveiro.

RESUMEN: INFLUENCIAS AMBIENTALES EN LA DISTRIBUCIÓN DE LA COMUNIDAD DE PECES EN UNA LAGUNA COSTERA ESTUÁRICA, Ria de Aveiro (Portugal). - La estructura espacial y estacional de la comunidad de peces fue examinada en una laguna costera estuárica, la Ria de Aveiro. La variación de las condiciones abióticas fue registrada durante dos años para identificar los factores responsables de mantener la estructura de las comunidades de peces. Nueve estaciones fueron muestreadas mensualmente con una red tradicional de arrastre tipo "chincha", entre noviembre 1998 y octubre de 2000. La abundancia y la biomasa variaron perceptiblemente entre las estaciones. La temperatura fue el factor abiótico más importante que afectó la distribución de la abundancia (número de individuos) de la comunidad de peces, fenómeno que se relaciona más con las migraciones estacionales que con las migraciones espaciales. La salinidad fue el siguiente factor abiótico más importante que afecta la biomasa de peces. Los otros parámetros abióticos analizados también demostraron una cierta influencia en la distribución de los peces, aunque, aislados de los otros factores controlados e incontrolados, no podrían explicar completamente todas las diferencias halladas en la comunidad. Los análisis de alimentación indican que la comunidad de peces es principalmente dependiente de los crustáceos de pequeño tamaño así como de detritos bentónicos y pelágicos, aunque pueden alimentarse de forma oportunística de otras presas. La baja segregación espacial de peces en lo referente a preferencia alimentícia indica que, en una laguna rica en alimento, como la Ria de Aveiro, las interacciones ambiental-biológicas aparecen tener un mayor efecto en la distribución de los peces que las interacciones biológicas.

Palabras clave: fauna de peces, diversidad, factores ambientales, Ria de Aveiro. 


\section{INTRODUCTION}

Assemblages of estuarine organisms vary in time and space, largely because estuaries have widely varying environmental characteristics and serve as nurseries for many productive and dependent marine species (Rogers et al., 1984 in Rakocinski et al., 1996; Elliott and Hemingway, 2002). The habitats and fish assemblages are also potentially affected by several anthropogenic influences which may have a direct influence on the food resources, distribution, abundance, growth, survival and behaviour of the fauna present (Whitfield, 1996).

The main estuarine water quality parameters, salinity, temperature, turbidity, $\mathrm{pH}$ and dissolved oxygen are known to affect fish distribution (Blaber and Blaber, 1980 in Marshall and Elliott, 1998). Sediment characteristics, substratum heterogeneity and vegetal cover also affect fish distribution through their influence on prey availability (Marchand, 1993) and/or protection from predators (Blaber and Blaber, 1980 in Marshall and Elliott, 1998).

The assessment of fish assemblage structure has a high value in estuarine quality assessment (Elliott et al., 1988; Pomfret et al., 1991) although causal links have to be determined between environmental parameters and fish assemblage structure and functioning. Identification of significant associations between fish species and habitat conditions is the first step towards incorporating environmental information into fish abundance (Perry et al., 1994). In general, the structure and functioning of fish communities within estuaries has been documented to a lesser extent than those of communities on the coast or in the open sea (Elliott and Taylor, 1989). The role of estuaries to commercial fish as spawning and nursery areas is relatively well understood (Haedrich, 1983), although further studies are required on aspects such as spatial usage and trophic interactions on fish assemblage.

The particular abiotic attributes of the Ria de Aveiro lagoon-shallowness, high turbidity, nature of the substrate, temperature, salinity and oxygenare associated with its high biotic productivity and offer excellent conditions for colonisation by many species, especially teleosts (Potter et al., 1990; Rebelo, 1992; Pombo and Rebelo, 2002).

Concerning the availability of fish food within the lagoon, copepods are the most dominant group in the whole lagoon and decapods, isopods, mysids and amphipods are very abundant in most areas (Morgado, 1997). The density of the major domi- nant neritic zooplankton species was significantly correlated with salinity, while for estuarine species the density was significantly correlated with water temperature (Morgado, 1997). Another important study on peracaridan crustaceans (Cunha, 1999) recorded 69 species in the whole lagoon comprising 52\% amphipods, $19 \%$ isopods, $19 \%$ mysids, $6 \%$ cumaceans, and $4 \%$ tanaids, and also showed important spatial and temporal changes.

The biology and ecology of fish species in the Ria de Aveiro have been recently characterised in various studies (Rebelo, 1992; Rebelo and Pombo, 2001; Pombo and Rebelo, 2002; Pombo et al., 2002a). Despite these studies, the environmental effects on abundant fish distribution in Ria de Aveiro have not been studied as in other estuaries and lagoons (Pomfret et al., 1991; Marchand, 1993; Jones et al., 1996; Pope and Willis, 1996; Marshall and Elliott, 1996, 1998; Irigoien et al., 1999; DuffyAnderson and Able, 1999; Kuo et al., 2001).

The present study aims to assess the spatial and temporal characteristics and assemblage structure of abundant fish populations within an estuarine coastal lagoon. The consistence data of this paper is established by month samplings during two subsequent years. This study attempts to improve the knowledge of whether the fish assemblage changes in a predictable way as abiotic factors change, and whether different sites differ significantly in the fish assemblage. The interactions of feeding habits of abundant fish species were also examined.

\section{MATERIAL AND METHODS}

\section{Study Area}

The Ria de Aveiro (Fig. 1), on the west coast of Portugal, is a coastal estuarine lagoon with a maximum length of $45 \mathrm{~km}$ and a maximum width of 11 $\mathrm{km}$ delimiting a total area of between $42 \mathrm{~km}^{2}$ (low tide) and $47 \mathrm{~km}^{2}$ (high tide) (Barrosa, 1980). The water volume is 70 million $\mathrm{m}^{3}$, with an oceanic tidal contribution of between 25 million $\mathrm{m}^{3}$ (neap tides) and 90 million $\mathrm{m}^{3}$ (higher spring tides). Four rivers (the Vouga, Antuã, Caster and Boco) and countless streams flow between $3 \mathrm{~m}^{3} \mathrm{~s}^{-1}$ and $60 \mathrm{~m}^{3} \mathrm{~s}^{-1}$, due to the influence of seasonal precipitation and runoff patterns. The depth varies between $0.6 \mathrm{~m}$ and 10.0 $\mathrm{m}$. The nature of the sediments, in particular the granulometry, is extremely variable. Its composition varies between 20 and $90 \%$ of sand, 10 and $80 \%$ of 


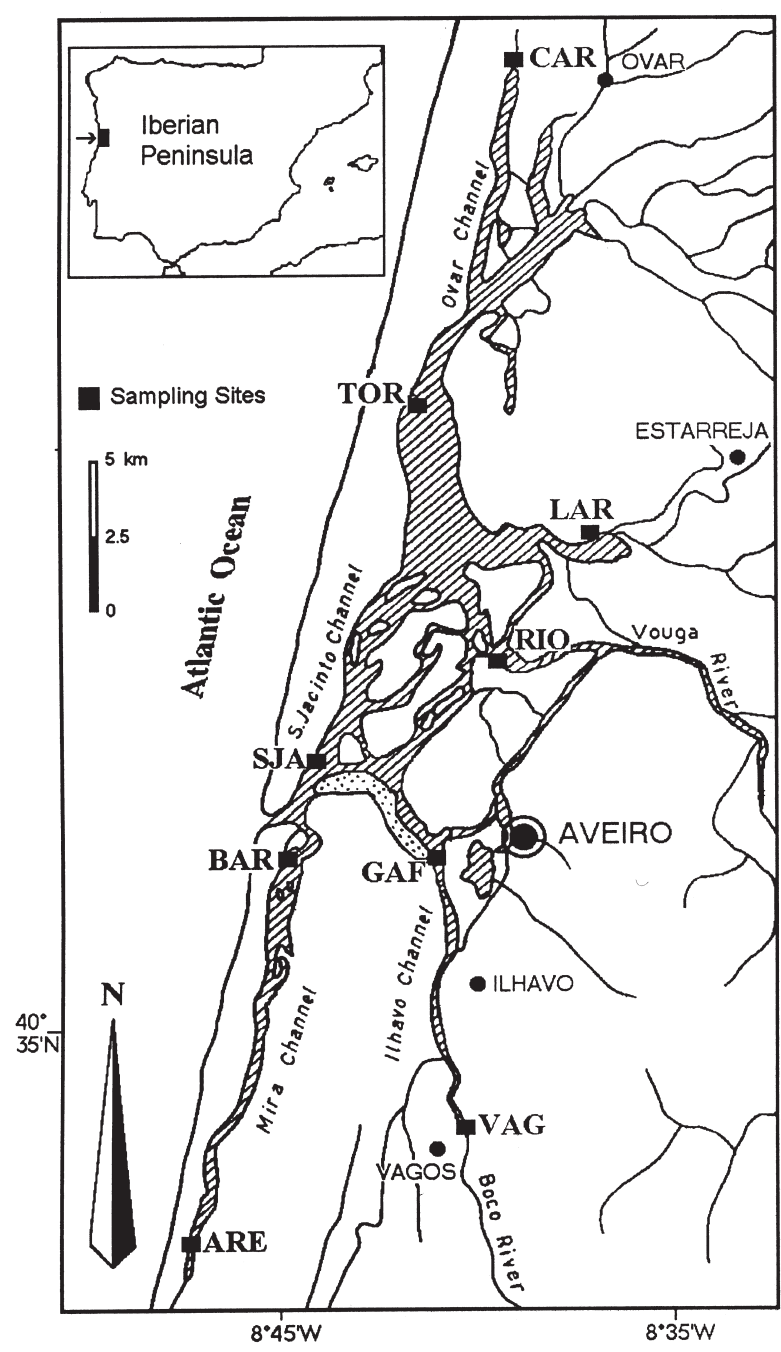

FIG. 1. - Map of the Ria de Aveiro lagoon showing sampling sites.

silt and 0 and $30 \%$ of clay. In the north the sediments are finer but become coarser with progression to the south (Borrego et al., 1994).

The lagoon receives considerable raw and treated wastewater effluent and three main pollution types are apparent: organic and chemical pollution from paper-pulp factories (in the rivers Vouga and Antuã); chemical pollution, particularly mercury, from the industrial area of Estarreja (in the Laranjo area); and microbial contaminants from the urban sewage effluent and cattle raising areas (Ílhavo channel, Vouga river and Ovar channel) (Hall, 1980; Lima, 1986; Lucas et al., 1986; Borrego et al., 1994).

\section{Sampling techniques}

Fish were sampled monthly between November 1998 and October 2000 with "chincha", a traditional beach-seine net. The "chincha" gear used was almost rectangular in shape and composed of a central bag (a 'cod-end', $295 \mathrm{~cm}$ long and $145 \mathrm{~cm}$ wide), two lateral wings ( $12 \mathrm{~m}$ long each, the width decreasing along the net, reaching $50 \mathrm{~cm}$ at the edge), two ropes ( $6.1 \mathrm{~m}$ each), floating buoys at the top and ceramic weights at the bottom of the net. The stretched mesh sizes in the gear were $19 \mathrm{~mm}$ at the wings, $17 \mathrm{~mm}$ at the cod mouth, $16 \mathrm{~mm}$ at the cod sleeve, and $10 \mathrm{~mm}$ at the cod-end. The end of the net was fixed to the margin and the remainder was trawled in a semi-circle, thus retaining within the cod-end all the fish from the area. The net efficiency is estimated at $90 \%$ (Elliott and Hemingway, 2002).

At each site and each month, 3 non-overlapping replicate samples were taken at low spring tide over the five days of the new moon at adjacent, non-overlapping areas: near the mouth of the lagoon (BAR, GAF and SJA); at the edges of the main channels (ARE, CAR and VAG); in the highly organically enriched (RIO) main freshwater area; in the area showing the highest levels of industrial pollution (LAR), and approximately in the middle of the longest channel (TOR) (Fig. 1).

The fishes were preserved by freezing and they were identified using taxonomic keys of Whitehead et al. (1986) and Bauchot and Pras (1987). The total fresh weight was measured with an electronic balance (And FX - 300).

\section{Data analysis}

Fish were grouped by ecological guilds following the classification of Elliott and Dewailly (1995): (1) ER, estuarine residents; (2) MJ, marine juveniles; (3) MS, marine seasonal; (4) FW, freshwater; (5) MA, marine adventitious; (6) CA, catadromous; and (7) AN, anadromous species.

Ten fish species were selected (Table 1) for this study, consisting in the maximum of two most abundant species of each ecological guild, considering the total abundance of two years (Fig. 2). As the choice of species with low abundance (less than 30 individuals in each year) could be questionable, only one species was selected for adventitious species and none for freshwater species. For catadromous species only one species is present in the lagoon.

The abundance (number of individuals) and biomass (wet weight individually recorded) distribution of species were established. The total percentage refers to the individuals collected for one species in the lagoon, considering all the replicas, which indi- 
TABLE 1. - Number of individuals and biomass (g) of fish sampled in 1999 and 2000 grouped by ecological guilds, according to Elliott and Dewailly (1995). Ten selected species are shown in bold type.

\begin{tabular}{|c|c|c|c|c|c|}
\hline \multirow{2}{*}{ Species } & \multirow[b]{2}{*}{ Code name } & \multicolumn{2}{|c|}{ Abundance } & \multicolumn{2}{|c|}{ Biomass (g) } \\
\hline & & 1999 & 2000 & 1999 & 2000 \\
\hline \multicolumn{6}{|l|}{ Estuarine Resident Species } \\
\hline Ammodytes tobianus & Atob & 9 & 0 & 102.1 & 0.0 \\
\hline Aphia minuta & Amin & 48 & 5 & 9.3 & 4.5 \\
\hline Atherina boyeri & Aboy & 2082 & 2911 & 5624.7 & 3074.2 \\
\hline Gobius ater & Gate & 1 & 4 & 9.4 & 54.0 \\
\hline Gobius niger & Gnig & 182 & 235 & 2732.5 & 3026.8 \\
\hline Gobius paganellus & Gpag & 18 & 2 & 189.4 & 13.4 \\
\hline Mugil cephalus & Mcep & 8 & 5 & 2457.0 & 2056.7 \\
\hline Nerophis ophidion & Noph & 1 & 0 & 3.0 & 0.0 \\
\hline Platichthys flesus & Pfle & 121 & 21 & 988.5 & 250.7 \\
\hline Pomatoschistus microps & Pmic & 526 & 338 & 443.4 & 192.3 \\
\hline Pomatoschistus minutus & Pmin & 75 & 47 & 69.3 & 105.1 \\
\hline Symphodus melops & Smel & 0 & 1 & 0.0 & 14.8 \\
\hline Syngnathus acus & Sacu & 203 & 200 & 729.3 & 1063.8 \\
\hline Syngnathus typhle & Styp & 6 & 6 & 15.2 & 2.6 \\
\hline \multicolumn{6}{|l|}{ Marine Juvenile Migrant Species } \\
\hline Atherina presbyter & Apre & 1011 & 1225 & 7078.3 & 6896.0 \\
\hline Dicentrarchus labrax & Dlab & 37 & 757 & 1456.0 & 7954.5 \\
\hline Dicentrarchus punctatus & Dpun & 5 & 0 & 34.4 & 0.0 \\
\hline Diplodus annularis & Dann & 2 & 0 & 14.9 & 0.0 \\
\hline Diplodus sargus & Dsar & 20 & 5 & 94.3 & 30.3 \\
\hline Diplodus vulgaris & Dvul & 4 & 0 & 155.3 & 0.0 \\
\hline Pleuronectes platessa & Ppla & 1 & 0 & 0.1 & 0.0 \\
\hline Scophthalmus rhombus & Srho & 0 & 3 & 0.0 & 18.7 \\
\hline Solea senegalensis & Ssen & 6 & 0 & 96.0 & 0.0 \\
\hline Solea solea & Ssol & 3 & 0 & 41.6 & 0.0 \\
\hline Spondyliosoma cantharus & Scan & 1 & 0 & 89.2 & 0.0 \\
\hline Trigla lucerna & Tluc & 202 & 32 & 4569.9 & 977.0 \\
\hline Trisopterus luscus & Tlus & 4 & 0 & 10.4 & 0.0 \\
\hline \multicolumn{6}{|l|}{ Marine Seasonal Migrant Species } \\
\hline $\begin{array}{l}\text { Chelon labrosus } \\
\text { Ciliata mustela }\end{array}$ & Clab & 140 & 14 & 1846.2 & 757.4 \\
\hline $\begin{array}{l}\text { Ciliata mustela } \\
\text { Engraulis encrasicolus }\end{array}$ & Cmus & $\begin{array}{r}22 \\
352\end{array}$ & $\begin{array}{r}6 \\
334\end{array}$ & 139.3 & 212.6 \\
\hline Engraulis encrasicolus & Eenc & 352 & 334 & 359.6 & 715.4 \\
\hline Liza aurata & Laur & 4273 & 5092 & 45624.5 & 50237.4 \\
\hline Sardina pilchardus & Spil & 8739 & 9478 & 13683.9 & 13694.3 \\
\hline \multicolumn{6}{|l|}{ Freshwater Adventitious Species } \\
\hline Carassius carassius & Ccar & 0 & 3 & 0.0 & 1346.4 \\
\hline Gambusia affinis & Gaff & 0 & 4 & 0.0 & 1.9 \\
\hline \multicolumn{6}{|l|}{ Marine Adventitious Visitors } \\
\hline Balistes carolinensis & Bcar & 1 & 0 & 379.4 & 0.0 \\
\hline Blennius gattorugine & Bgat & 8 & 10 & 37.8 & 45.0 \\
\hline Blennius sanguinolentus & Bsan & 1 & 0 & 7.6 & 0.0 \\
\hline Boops boops & Bboo & 2 & 1 & 89.8 & 0.4 \\
\hline Callionymus lyra & Clyr & 12 & 6 & 211.1 & 116.9 \\
\hline Conger conger & Ccon & 1 & 0 & 0.6 & 0.0 \\
\hline Deltentosteus quadrimaculatus & Dqua & 1 & 0 & 9.0 & 0.0 \\
\hline Echiichthys vipera & Evip & 0 & 1 & 0.0 & 19.2 \\
\hline Entelurus aequoraeus & Eaeq & 0 & 1 & 0.0 & 0.8 \\
\hline Hyperoplus lanceolatus & Hlan & 1 & 0 & 2.6 & 0.0 \\
\hline Labrus bergylta & Lber & 2 & 0 & 140.1 & 0.0 \\
\hline Labrus merula & Lmer & 1 & 0 & 59.4 & 0.0 \\
\hline Mullus surmuletus & Msur & 21 & 12 & 893.3 & 598.9 \\
\hline Pomatoschistus marmoratus & Pmar & 7 & 0 & 22.5 & 0.0 \\
\hline Psetta maxima & Pmax & 1 & 0 & 49.4 & 0.0 \\
\hline Scomber scombrus & Ssco & 1 & 0 & 19.2 & 0.0 \\
\hline Solea lascaris & Slas & 11 & 2 & 55.3 & 24.1 \\
\hline Sparus aurata & Saur & 0 & 8 & 0.0 & 97.4 \\
\hline Symphodus bailloni & Sbai & 93 & 159 & 1421.3 & 1417.5 \\
\hline Symphodus cinereus & Scin & 1 & 1 & 51.5 & 4.3 \\
\hline Trachurus trachurus & Ttra & 8 & 5 & 112.3 & 56.3 \\
\hline \multicolumn{6}{|l|}{ Catadromous Migrant Species } \\
\hline Anguilla anguilla & Aang & 53 & 46 & 2690.2 & 2031.8 \\
\hline \multicolumn{6}{|l|}{ Anadromous Migrant Species } \\
\hline Alosa alosa & Aalo & 4 & 3 & 287.1 & 57.5 \\
\hline Alosa fallax & Afal & 21 & 24 & 551.2 & 344.1 \\
\hline Gasterosteus aculeatus & Gacu & 0 & 13 & 0.0 & 182.5 \\
\hline Liza ramada & Lram & 627 & 1227 & 10587.2 & 11375.7 \\
\hline Liza saliens & Lsal & 444 & 10 & 6270.6 & 267.1 \\
\hline
\end{tabular}


cates the tendency of a species to have a preferential area with respect to other areas in each year separately. This enabled the statistical significance of the distribution to be determined. Thus, two-way ANOVA without replication (Zar, 1984; Sokal and Rohlf, 1995) was carried out for any single species to test significant differences between the total abundance and total biomass of each species between sites in each year. The same statistical test was assessed to test significant differences between the abiotic parameters between sites and between months. Homogeneity of variances was tested using the Fmax test (Zar, 1984; Sokal and Rohlf, 1995). The abiotic analysis was completed using a t-test for the mean of each parameter of each site to determine whether each abiotic parameter of each area in one year was different to the same area in the following year (Zar, 1984; Sokal and Rohlf, 1995).

Measurements of temperature $\left( \pm 0.1^{\circ} \mathrm{C}\right)$ and dissolved oxygen $\left( \pm 0.01 \mathrm{mg} . \mathrm{l}^{-1}\right)$ were taken with an oxygen meter (Consort Z621), salinity $( \pm 0.1)$ with a refractometer (Atago), and $\mathrm{pH}( \pm 0.01)$ with a $\mathrm{pH}$ meter $(W T W 330 /$ set -2$)$. These parameters were only recorded at the water surface since preliminary fieldwork had shown that water column differences were not significant (Rebelo, 1992). Turbidity $( \pm 0.1$ $\mathrm{m})$ and depth $( \pm 0.1 \mathrm{~m})$ were measured with a Secchi disc after fish samplings at low tide of spring tides. This sampling protocol is consistent with previous surveys within the area (Rebelo, 1992; Pombo and Rebelo, 2002; Pombo et al., 2002a).

Analysis of the assemblage was established on the abundance and biomass data using a canonical correspondence analysis (CCA), which enabled the assemblage data to be assessed with respect to the environmental parameters (ter Brack, 1986). It gave an assessment of the relative importance of the parameters to the distribution of each species, as well as the factors of most importance to the assemblage structure in terms of abundance and biomass. The importance of the environmental factors is indicated by the relative length of vectors: the longer the vector, the greater the influence on species distribution. In addition, the closer any two species are on the graph, the more similar is their distribution; a similar relationship exists to the environmental parameters (ter Brack, 1986). The nature of canonical correspondence analysis dictates that any species highly influenced by two variables will be positioned along the axis created by two vectors rather than at the end of any single vector (ter Brack, 1986). These relationships were completed performing the Spearman Rank correlation analysis. This univariate non-parametric statistical technique enables the relationship between species abundance or biomass and abiotic factors to be analysed individually and also allows one to identify which factor is responsible for maintaining the structure of fish assemblages in each year (Sokal and Rohlf, 1995).

\section{Diet analysis}

Stomach contents were analysed to the lowest possible taxonomic level, according to Hayward and Ryland, (1998), with a stereomicroscope (Olympus SZ60-PT) (630x) and an optical microscope (Olympus $\mathrm{CH} 30$ ) (1000x). The level of identification of food items is a function of the digestion stage of prey (Rosecchi and Nouaze, 1985). Crustaceans were identified from some parts of the body that allow their individualisation, such as the heads for amphipods, or cephalothoraxes or abdomina for mysids and decapods (Kara and Derbal, 1996). A small number of other items found in stomachs (e.g. mollusc shells and both larval and post-larval crustaceans, and parasitic worms) were considered as miscellaneous or non-food items, probably ingested incidentally in normal feeding. Prey that were too digested for unequivocal identification to the lowest taxonomic level were assigned as n.i. (non-identified prey).

The diet composition of each species was analysed for the frequency of occurrence of prey items. Frequency of occurrence of a given prey type was defined as the number of stomachs in which that prey occurs, expressed as a frequency of a total number of stomachs in which prey are present (Hyslop, 1980). Fish size will affect the prey taken (Wootton, 1990 in Marshall and Elliott, 1996), so the size of each fish was noted and grouped as small, medium and large individuals in species in which length was significant at this level. The size classes were determined using the maximum and minimum length of fish (total length). When the size classes included few data (fewer than 30 stomachs), only two groups were considered (small and large) or even no groups at all.

A Bray-Curtis similarity coefficient was performed based on the frequency of occurrence of prey to indicate the degree of feeding similarities and therefore the inter- and intraspecific dietary interactions within the estuary. 


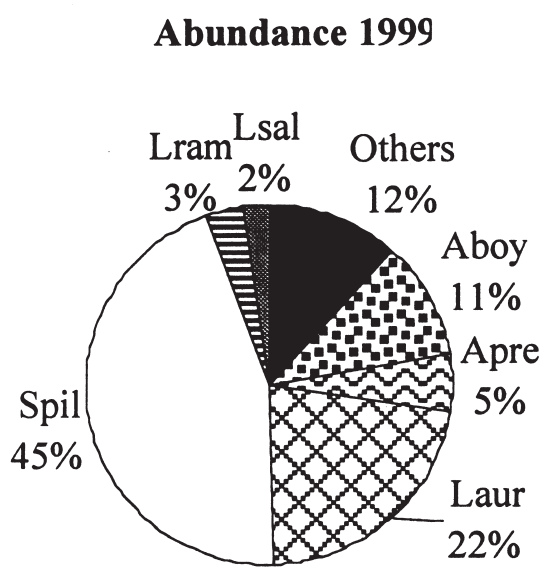

Biomass 1999

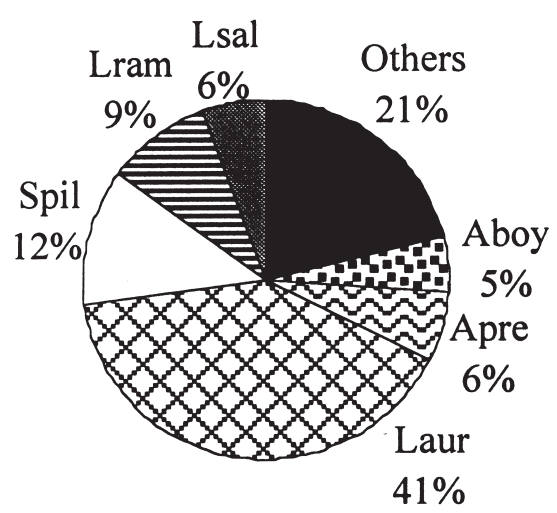

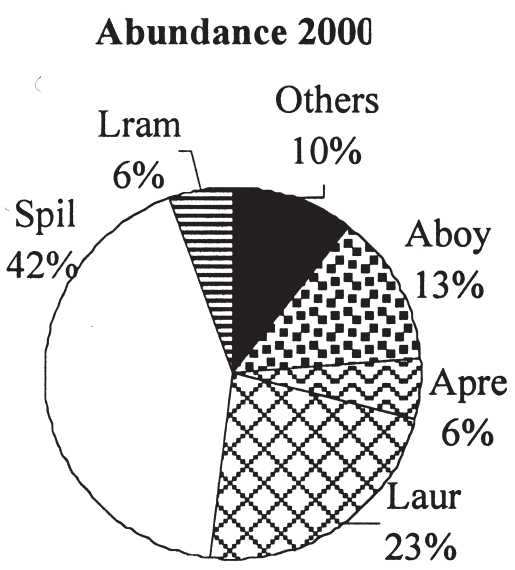

Biomass 2000

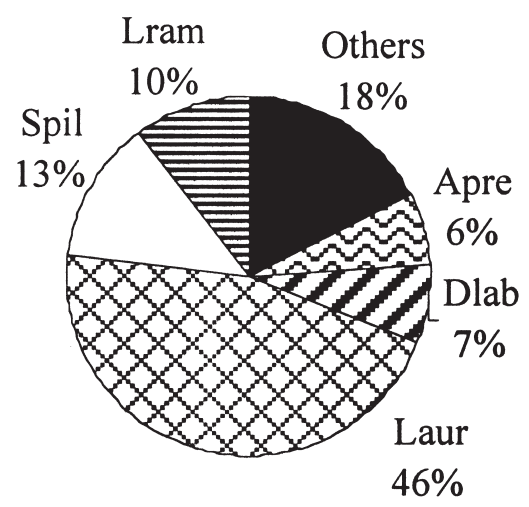

FIG. 2. - Pie charts of percentage of fish abundance and biomass for each year. Species code names are provided in Table 1.

\section{RESULTS}

\section{Assemblage structure}

A total of 61 teleost species were identified from 41,681 specimens $(19,424$ in the first year and 22,257 in the second year) with a total biomass of $222 \mathrm{~kg}(113 \mathrm{~kg}$ in the first year and $109 \mathrm{~kg}$ in the second year) (Table 1). Of the 61 species captured in the two years of sampling, only 33 species were common in two years, 20 species were exclusive to 1999 and 8 were exclusive to 2000 .

The marine seasonal $(68 \%)$ and estuarine resident species (17\%) accounted for $85 \%$ of total abundance and $67 \%$ of total biomass collected during the whole period. Thirteen species were marine juvenile migrant species, comprising $8 \%$ of total numbers and $13 \%$ of total biomass. Twenty species were transient visitors of the lagoon, but they comprised a low number of the fish collected (1\% of total individuals and $3 \%$ of total biomass). Only five species were anadromous and one catadromous, accounting for $6 \%$ of total individuals and $13 \%$ of the total bio- mass, and only two freshwater species accounted for 7 individuals that sporadically occurred in the lagoon (Table 1).

The ten selected species (in bold type in Table 1) comprised $92 \%$ of total abundance and $84 \%$ of total biomass in the first year and $95 \%$ of total abundance and $89 \%$ of total biomass in the second year. From the ten selected species, six were present at every sampling site: S. pilchardus, L. aurata, A. boyeri, A. presbyter, D. labrax, and L. ramada.

S. pilchardus was the most abundant species in both years, comprising $44 \%$ of total numbers and $12 \%$ of total biomass (Fig. 2). L. aurata, also a seasonal marine species, comprised $22 \%$ of total numbers and $43 \%$ of total biomass (Fig. 2). The next two most abundant species, A. boyeri (resident) and $A$. presbyter (marine juvenile), accounted together for about $17 \%$ of total numbers, and about $10 \%$ of total biomass.

During two subsequent years, the spatial distribution of most species was significantly different (Fig. 3 and Fig. 4). Only L. ramada, in the first year, and $S$. pilchardus, in the second year, failed to show 


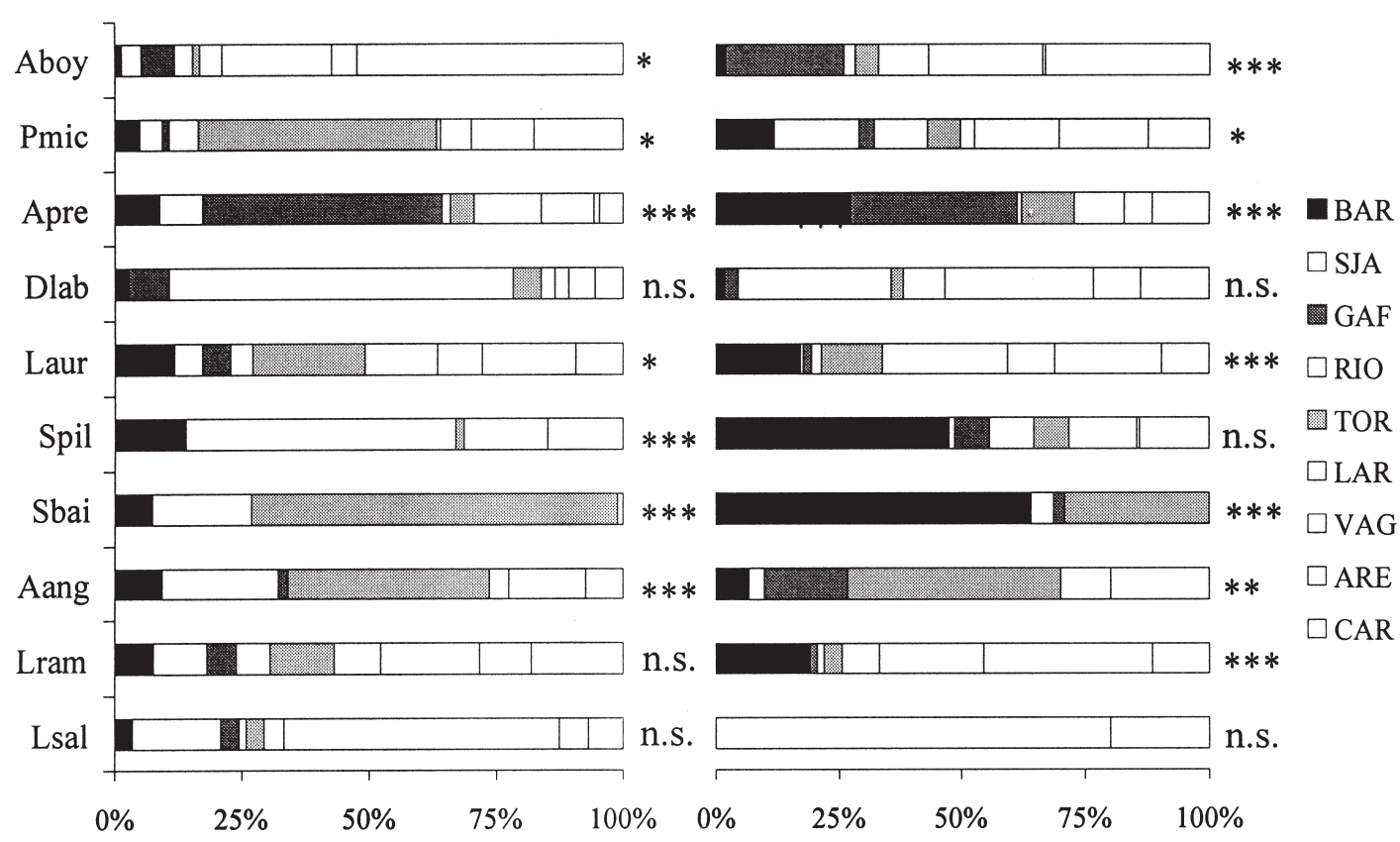

FIG. 3. - Distribution of species at each site, as a percentage of abundance over the study period; each graph corresponds to a sampling year. Species code names are provided in Table 1, and site abbreviations are explained in the text and shown in Figure 1. Significant differences of species abundance within sites are shown. n.s.: $\mathrm{p}>0.05 ;(*): \mathrm{p} \leq 0.05 ;(* *): \mathrm{p} \leq 0.01 ;(* * *): \mathrm{p} \leq 0.001$.

1999

2000

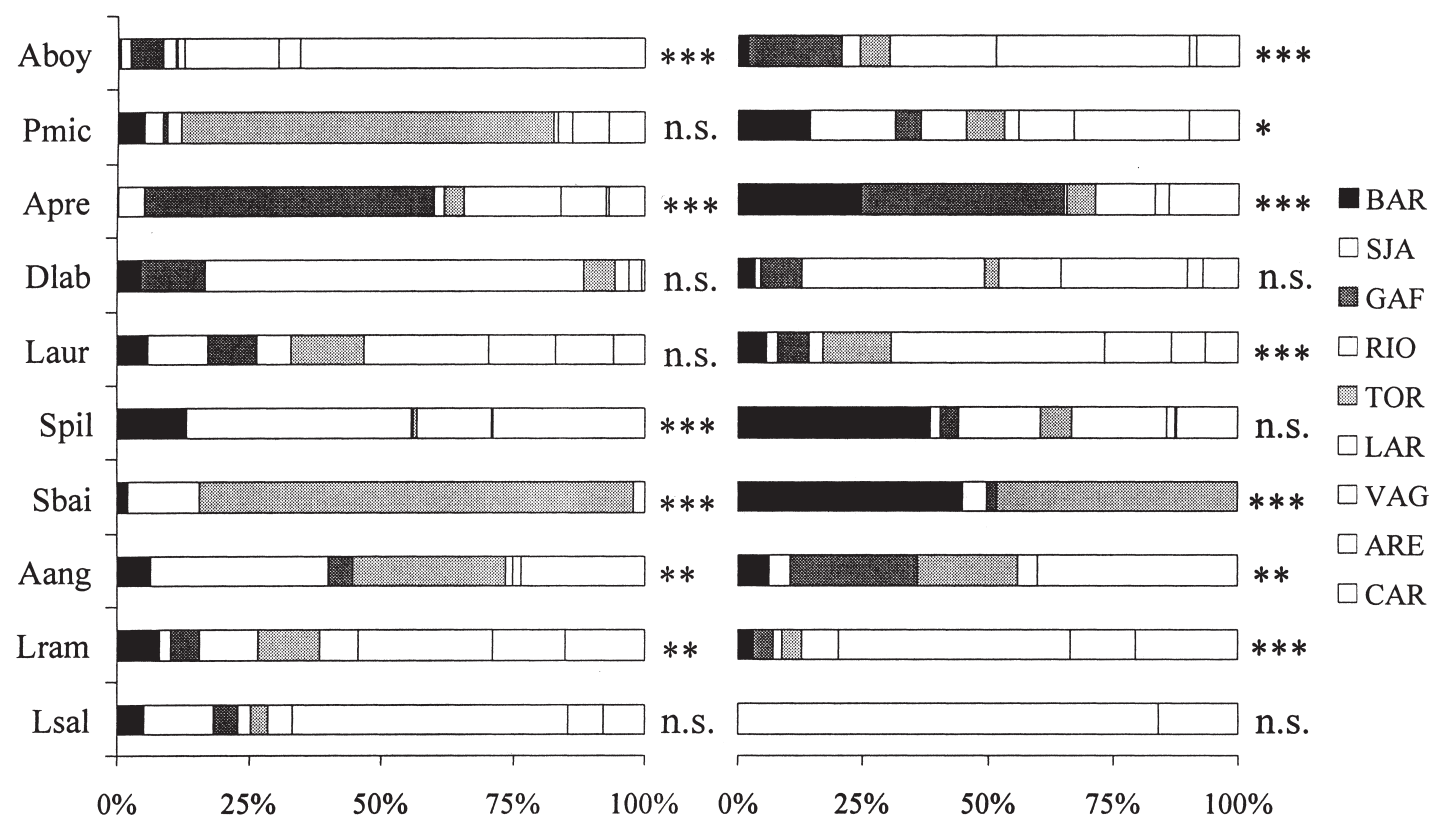

FIG. 4. - Distribution of species at each site, as a percentage of biomass over the study period; each graph corresponds to a sampling year. Species code names are provided in Table 1, and site abbreviations are explained in the text and shown in Figure 1. Significant differences of species abundance within sites are shown. n.s.: $\mathrm{p}>0.05 ;(*): \mathrm{p} \leq 0.05 ;(* *): \mathrm{p} \leq 0.01 ;(* * *): \mathrm{p} \leq 0.001$.

a significantly different distribution within the lagoon. The distribution of D. labrax and L. saliens was not statistically significant in both years (Fig. 3 ). The spatial distribution of biomass was quite similar to that of abundance.

\section{Abiotic parameters}

The average, minimum and maximum values of the environmental data are clear in each year by site (Fig. 5) and by month (Fig. 6). Sampling sites 

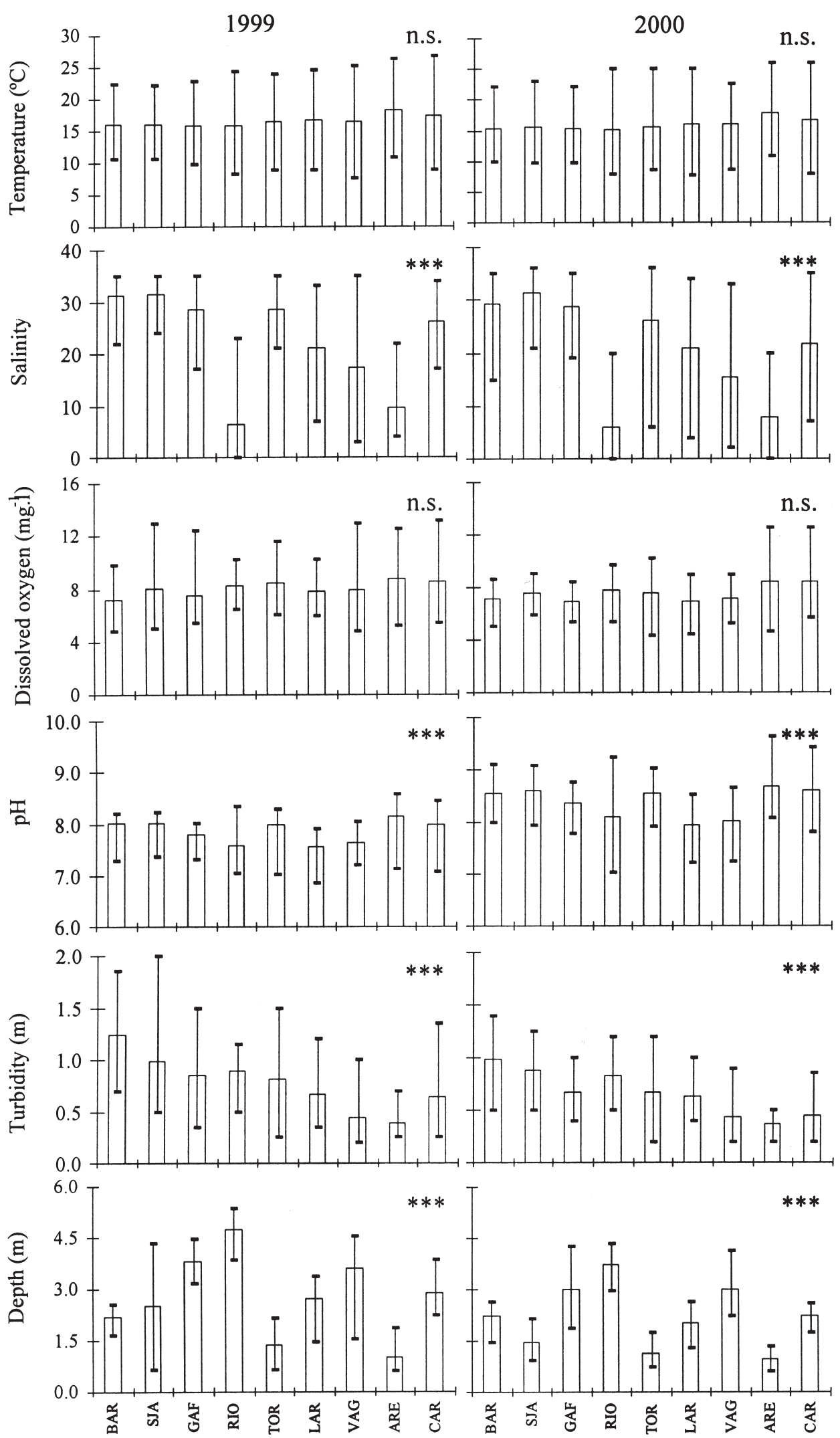

FIG. 5. - Minimum, average and maximum values of abiotic parameters by sampling sites; each column of graphs correspond to a sampling year. Site abbreviations are explained in the text and shown in Figure 1. Significant differences of abiotic parameters between sites along months are shown. n.s.: $\mathrm{p}>0.05 ;(*): \mathrm{p} \leq 0.05 ;(* *): \mathrm{p} \leq 0.01 ;(* * *): \mathrm{p} \leq 0.001$ 

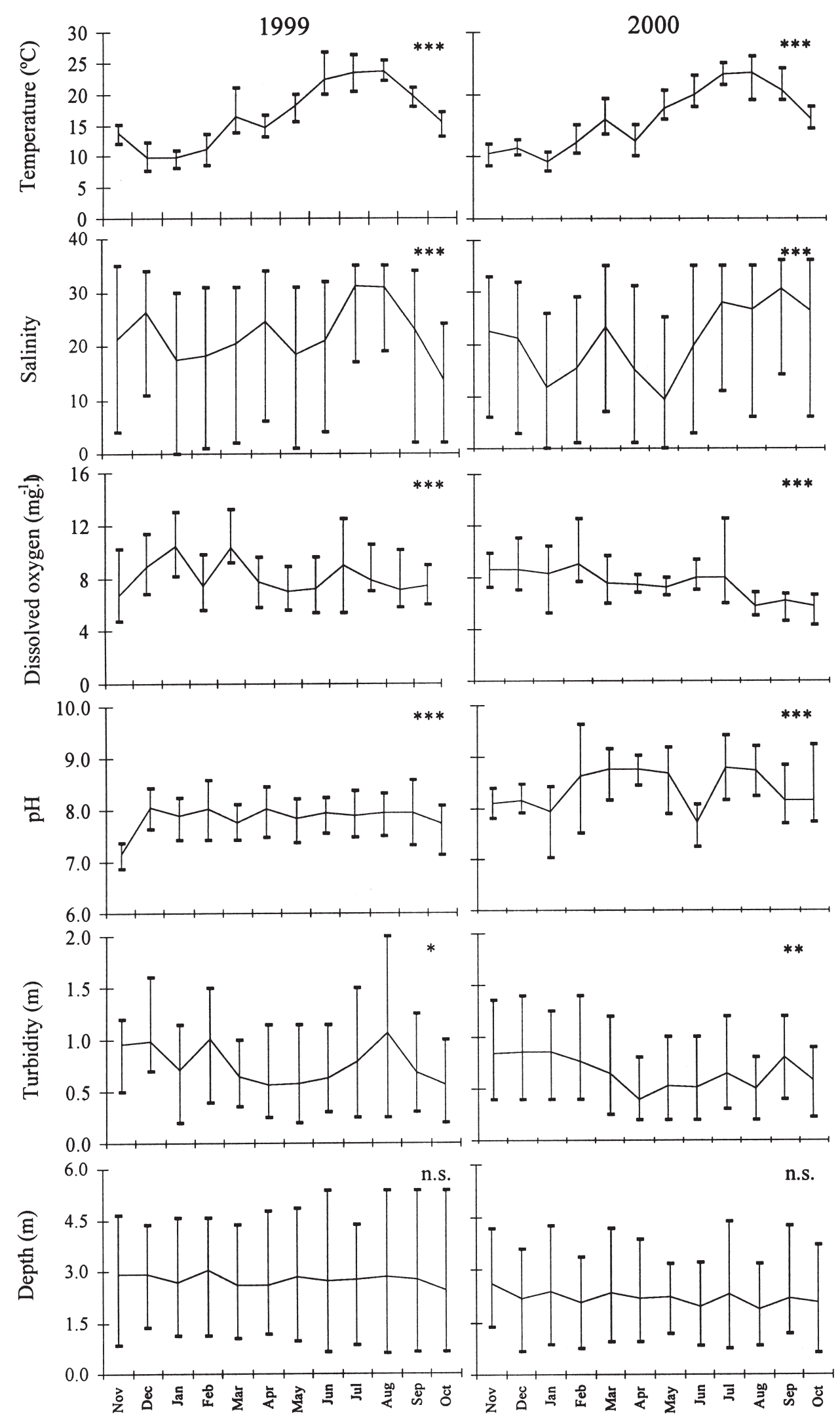

FIG. 6. - Minimum, average and maximum values of abiotic parameters by sampling months in each year. Significant differences of abiotic parameters between months are shown. n.s.: $\mathrm{p}>0.05 ;(*): \mathrm{p} \leq 0.05 ;(* *): \mathrm{p} \leq 0.01 ;(* * *): \mathrm{p} \leq 0.001$. 
are presented in the graphs according to the minor distance to the lagoon entrance. All the abiotic parameters analysed here, except temperature and dissolved oxygen, were spatially significantly different. On the other hand, only depth did not show seasonally statistically significant, as climatic factors were major determinants to the seasonal changes (Fig. 6).

The differences in temperature between the two sampling years were not statistically different $(\mathrm{p}=0.801)$. Temperature was markedly different between months, with higher values in summer months $\left(27^{\circ} \mathrm{C}\right)$ and lower values in winter months $\left(7.6^{\circ} \mathrm{C}\right)$ (Fig. 6). Salinity varied from typical freshwater (ARE and RIO), brackish water (VAG, LAR and CAR), and marine water (BAR, SJA, GAF and TOR) (Fig. 5) close to the mouth of the lagoon. Salinity decreased gradually towards the upper reaches of the channels, with a significant freshwater inflow, but in some remote shallow areas the circulation was low and a concentration of salts could eventually occur during summer. At times of maximum freshwater discharge resulting from continued rainy periods, in the second year, the salinity was severely decreased all over the lagoon, although it was not significant $(\mathrm{p}=0.570)$ (Fig. 5). Dissolved oxygen varied from levels near anoxia $\left(4 \mathrm{mg} \mathrm{l}^{-1}\right)$ in winter to oversaturated values $\left(13 \mathrm{mg} \mathrm{l}^{-1}\right)$ in summer, but these values were not significant within the lagoon. There was no statistically significant difference, in the whole lagoon, between the two years $(\mathrm{p}=0.310)$. $\mathrm{pH}$ changed significantly both temporal-

\section{9}

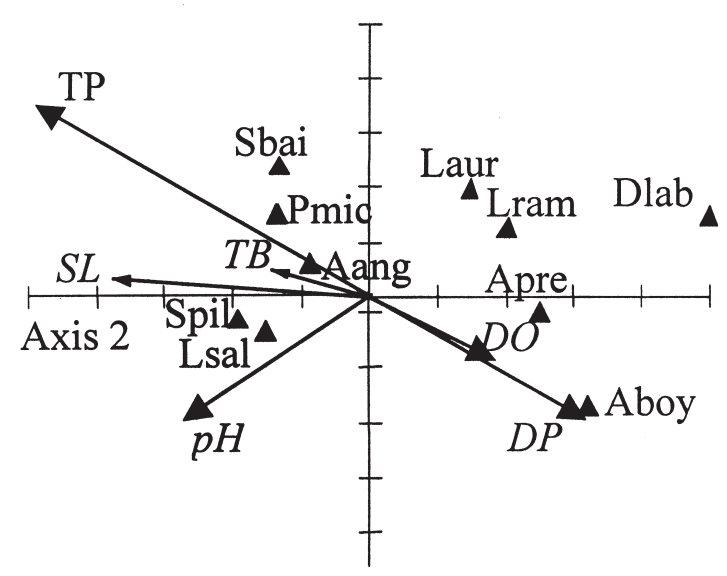

Axis 1 ly and spatially (Figs. 5 and 6), between acid (6.81) in the regions with higher chemical pollution problems - especially $\mathrm{Hg}$ concentrations from the industrial complex of Estarreja (LAR) (Fig. 1) - and alkaline (9.62) in the regions with urban effluents and farming activities (Ílhavo channel, Vouga River and Ovar channel) (VAG, RIO and CAR) (Fig. 1). There was a statistical difference $(\mathrm{p}<0.001)$ of $\mathrm{pH}$ values at all the sites from the first to the second year, showing an increase in alkalinity. Turbidity showed both a temporal and a spatial variation varying between $20 \mathrm{~cm}$ at the edges during summer and $2 \mathrm{~m}$ near the mouth of the lagoon during winter (Fig. 5 and 6), where the currents are stronger. There was no significant variation between the first and the second year $(p=0.088)$ at any sites or in any months. Depth varied significantly $(p<0.001)$ from the edges of channels $(0.5 \mathrm{~m})$ (ARE at south and TOR at north) to the inner regions of the lagoon $(6 \mathrm{~m})$ (RIO, VAG and LAR) (Fig. 5) but this difference was not significant during the months in each year (Fig. 6). There was a significant decrease in depth $(\mathrm{p}<0.001)$ between the two years of fish sampling at most sites (with the exception of the shallow sites ARE, BAR and TOR).

\section{Environmental influences on fish distribution}

The relative importance of the measured environmental factors to the fish abundance and biomass is shown in Figures 7 and 8, as determined by canonical correspondence analysis. Only axes 1 and

\section{0}

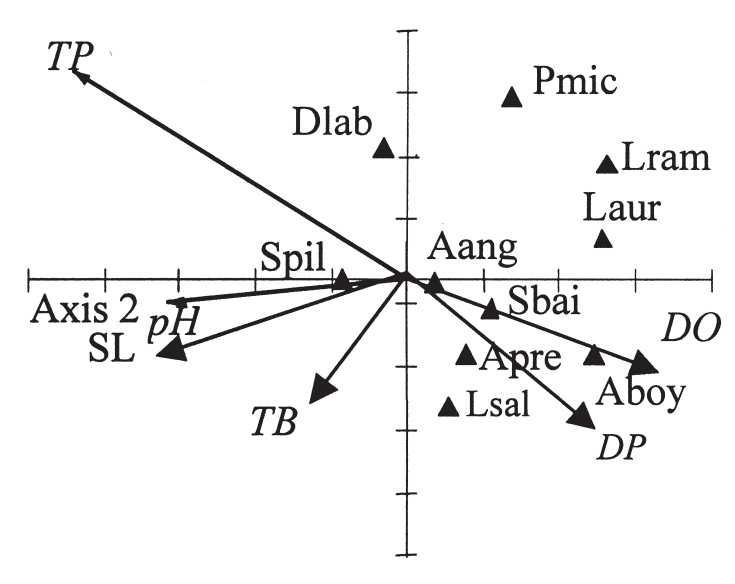

Axis 1

FIG. 7. - CCA ordination diagram of Ria de Aveiro dominant fish abundance with environmental factors represented by arrows: temperature (TP); salinity (SL); dissolved oxygen (DO); pH (pH); turbidity (TB) and depth (DP). Species codes are provided in Table 1. 


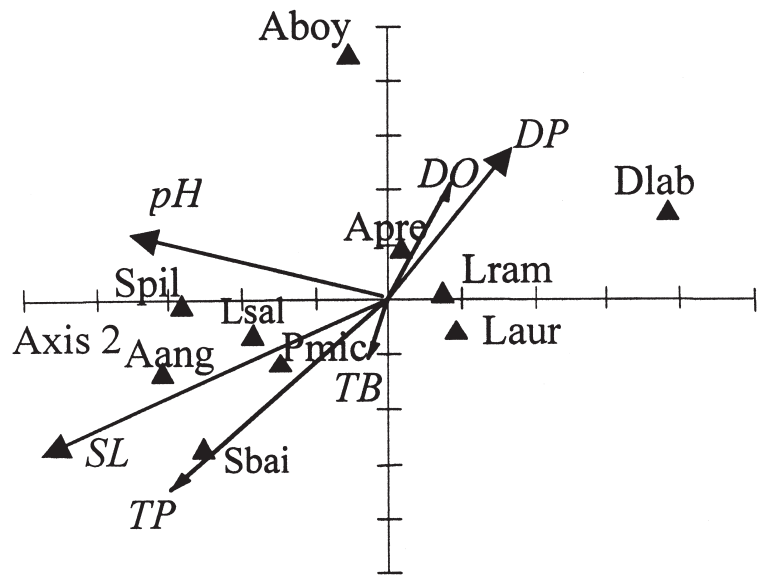

Axis 1

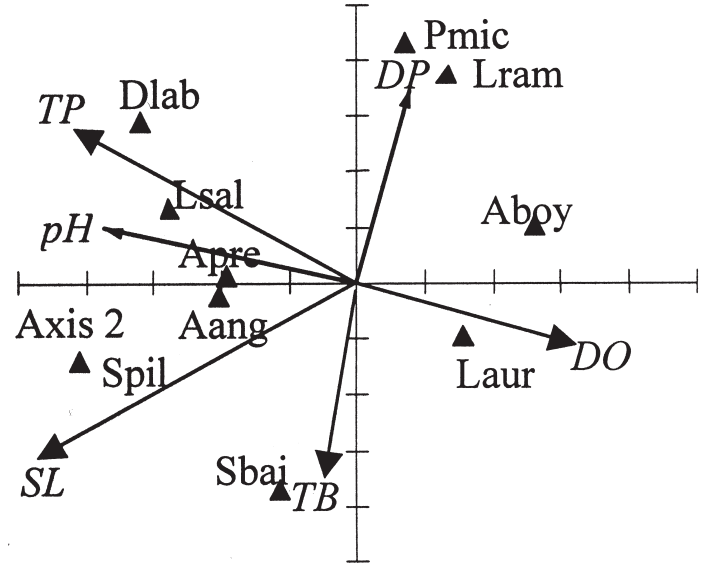

Axis 1

FIG. 8. - CCA ordination diagram of Ria de Aveiro dominant fish biomass with environmental factors represented by arrows: temperature (TP); salinity (SL); dissolved oxygen (DO); $\mathrm{pH}(\mathrm{pH})$; turbidity (TB) and depth (DP). Species codes are provided in Table 1.

2 were plotted, as they accounted for $82 \%$ and $80 \%$ respectively of the total variability in each year for the abundance data, and $71 \%$ and $81 \%$ in each year for the biomass data.

The relative lengths of the vectors indicate that temperature was the most important abiotic factor in the abundance distribution of species (Fig. 7), reflecting the seasonally varying nature of the assemblage and proving to be the best predictor of total abundance. The majority of species had a higher abundance above average temperature and occurred in the areas near the mouth of the lagoon, where the salinity and depth were also high; this was especially the case for the adventitious and seasonal migrant species. Temperature was positively correlated to abundance of $A$. anguilla in the first year and S. pilchardus and D. labrax in the second year, and negatively correlated to L. ramada in the second year (Table 2 and Fig. 7).

Analyses of the biomass data (Fig. 8) gave a slightly different grouping of species around the environmental variables and the relative importance of variables was also different. Salinity was found to be the most important abiotic factor affecting the fish biomass, though temperature also showed an influence on the distribution of fish biomass. Salinity and temperature were positively correlated to $S$. pilchardus and $A$. anguilla, which occurred with high biomass near the mouth of the lagoon and in the middle of the main channel (Fig. 4) with high salinity (Fig. 5), especially in summer, with high temperature.

The positions of turbidity, depth, dissolved oxygen and $\mathrm{pH}$ vectors may result in a skewing of the species distribution. The turbidity negatively influenced the abundance distribution of A. presbyter and $L$. ramada in both years (Table 2 ) but only influenced the biomass of the latter species (Table 3). Depth negatively influenced the distribution (abundance and biomass) of $S$. bailloni and A. anguilla, and positively influenced the distribution of $A$. boyeri (Tables 2 and 3). In the first year, dissolved oxy-

TABLE 2. - Correlation between fish abundance and environmental factors in 1999 and 2000. Species codes are provided in Table 1 . TP, temperature $\left({ }^{\circ} \mathrm{C}\right)$; SL, salinity; OD, dissolved oxygen $\left(\mathrm{mg} \mathrm{l}^{-1}\right)$; $\mathrm{pH}, \mathrm{pH}$; TB, turbidity $(\mathrm{m})$; DP, depth (m). Significant correlations between species abundance and abiotic parameters are shown. Blanks: $\mathrm{p}>0.05,(+$ or -$)$ : $\mathrm{p} \leq 0.05,(++$ or --$)$ : $\mathrm{p} \leq 0.01,(+++$ or ---$)$ : $\mathrm{p} \leq 0.001$.

\begin{tabular}{|c|c|c|c|c|c|c|c|c|c|c|c|c|c|c|c|}
\hline & $\begin{array}{c}\text { Aboy } \\
19992000\end{array}$ & $\begin{array}{c}\text { Pmic } \\
19992000\end{array}$ & $\begin{array}{c}\text { Apre } \\
19992000\end{array}$ & $\begin{array}{r}\text { D } \\
1999\end{array}$ & $\begin{array}{l}\text { Dlab } \\
92000\end{array}$ & $\begin{array}{r}\text { L } \\
1999\end{array}$ & 2000 & $\begin{array}{r}\mathrm{S}_{1} \\
1999\end{array}$ & pil 2000 & $\begin{array}{r}\text { Sbe } \\
1999\end{array}$ & 2000 & $\begin{array}{r}\text { Aar } \\
1999\end{array}$ & ng & $\begin{array}{c}\text { Lram } \\
19992000\end{array}$ & $\begin{array}{c}\text { Lsal } \\
19992000\end{array}$ \\
\hline $\mathrm{TP}$ & & & & & +++ & & & + & +++ & & & ++ & & - & \\
\hline SL & & & $+++\quad+++$ & & + & & & ++ & +++ & + & +++ & & +++ & & \\
\hline DO & & + & & + & --- & & & & --- & & & & & & \\
\hline $\mathrm{pH}$ & & + & & & & & & & & & & ++ & & & - \\
\hline TB & & & - & & & & & & & & +++ & & & --- & - \\
\hline DP & ++ & & & & & -- & --- & & & --- & -- & --- & & & \\
\hline
\end{tabular}


TABLE 3. - Correlation between fish biomass and environmental factors in 1999 and 2000. Species codes are provided in Table 1. TP, temperature $\left({ }^{\circ} \mathrm{C}\right)$; $\mathrm{SL}$, salinity; OD, dissolved oxygen $\left(\mathrm{mg} \mathrm{l}^{-1}\right) ; \mathrm{pH}, \mathrm{pH}$; TB, turbidity $(\mathrm{m})$; DP, depth $(\mathrm{m})$. Significant correlations between species biomass and abiotic parameters are shown. Blanks: $\mathrm{p}>0.05,(+$ or -$)$ : $\mathrm{p} \leq 0.05,(++$ or --$)$ : $\mathrm{p} \leq 0.01,(+++$ or ---$)$ : $\mathrm{p} \leq 0.001$.

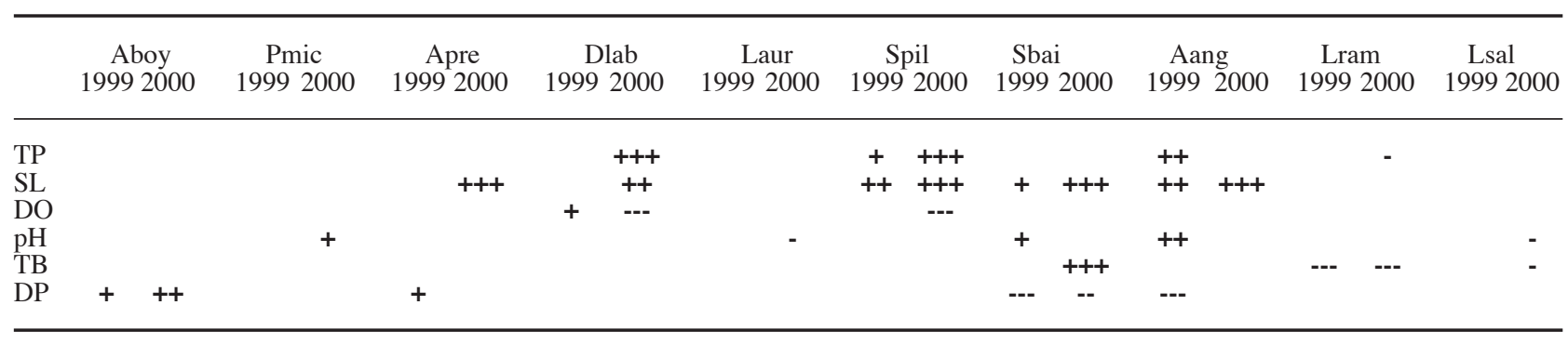

TABLE 4. - Food items frequency of occurrence on abundant species during 1999. Species abbreviations are explained in Table 1, and guild abbreviations are explained in the text.

\begin{tabular}{|c|c|c|c|c|c|c|c|c|c|c|}
\hline \multirow[t]{2}{*}{ Food items } & \multicolumn{2}{|c|}{ ER } & \multicolumn{2}{|c|}{ MJ } & \multicolumn{2}{|c|}{ MS } & \multirow{2}{*}{$\begin{array}{r}\text { MA } \\
\text { Sbai }\end{array}$} & \multirow{2}{*}{$\begin{array}{c}\text { CA } \\
\text { Aang }\end{array}$} & \multicolumn{2}{|c|}{ AN } \\
\hline & Aboy & Pmic & Dlab & Apre & Laur & Spil & & & Lram & Lsal \\
\hline \multicolumn{11}{|l|}{ Phylum Annelida } \\
\hline Polychaeta & 7.4 & 2.8 & 30.0 & 10.1 & 1.3 & 1.3 & 1.2 & 12.3 & - - - & 1.4 \\
\hline Annelida n.i. & 31.5 & $-\cdots$ & 10.0 & 29.7 & 0.3 & 0.7 & 1.2 & 6.2 & 0.3 & 0.7 \\
\hline \multicolumn{11}{|l|}{ Phylum Mollusca } \\
\hline Gastropoda & 4.5 & 1.9 & $-\ldots$ & 7.3 & 0.8 & 2.6 & $-\ldots$ & 2.5 & 0.6 & $-\ldots$ \\
\hline Bivalvia & 9.9 & 4.6 & - . - & 20.0 & 1.8 & 3.9 & 4.8 & 1.2 & 3.2 & 0.7 \\
\hline \multicolumn{11}{|l|}{ Phylum Artropoda } \\
\hline Chironomidae & - - - & $\ldots$ & $\ldots$ & $\ldots$ & 0.2 & $\ldots$ & - - - & - - - & 0.3 & - . - \\
\hline Formicidae & . . - & $\ldots$ & $\ldots$ & 0.8 & $\ldots$ & $\ldots$ & . . - & . . - & $\ldots$ & . . - \\
\hline Insecta larva & 10.0 & - . & 3.3 & 7.3 & 2.0 & 2.0 & 1.2 & 2.5 & 1.3 & 0.7 \\
\hline Insecta n.i. & 11.2 & 6.5 & $-\ldots$ & 17.4 & 3.7 & 2.6 & 2.4 & 3.7 & 3.2 & 0.7 \\
\hline \multirow{2}{*}{\multicolumn{11}{|c|}{$\begin{array}{c}\text { Phylum Crustacea } \\
\text { Microcrustacea }\end{array}$}} \\
\hline & & & & & & & & & & \\
\hline Branchiopoda & $\ldots$ & $\ldots$ & $\ldots$ & $\ldots$ & 0.1 & $\ldots$ & $\ldots$ & $\ldots$ & $\ldots$ & $\ldots$ \\
\hline Cumacea & - . - & - - - & - - - & 0.6 & $-\ldots$ & 1.3 & $-\ldots$ &.- & $-{ }_{-}$ & -- \\
\hline Ostracoda & 1.7 & 2.8 & - - - & 1.7 & 0.2 & - - & - . - & - . - & - . - & 0.7 \\
\hline Copepoda & 7.9 & 2.8 & 3.3 & 4.5 & 2.7 & 8.6 & 1.2 & 2.5 & 3.8 & 2.1 \\
\hline Crustacea larvae & $\ldots$ & $\ldots$ & - - - & 0.3 & 0.1 & 3.3 & 3.6 & $\ldots$ & $\ldots$ & - . - \\
\hline \multicolumn{11}{|l|}{ Small benthic crustacea } \\
\hline Gnatia sp. & - . - & - - - & - . & 0.6 & - . & - . - & - . - & - . - & - - - & - - - \\
\hline Idotea sp. & 1.2 & 2.8 & $\ldots$ & 1.4 & 0.2 & 0.7 & 22.9 & 1.2 & - - - & - - - \\
\hline Sphaeroma sp. & 31.0 & 10.2 & 20.0 & 24.7 & 0.4 & 0.7 & 4.8 & 6.2 & 0.3 & 0.7 \\
\hline Isopoda n.i. & -- & 1.9 & -- & 0.8 & -- & 0.7 & 7.2 & --- & 0.3 & -- \\
\hline Ampithoe sp. & $-{ }_{-}$ & - & - . & 0.3 & - . & - - & 1.2 & - - - & - - - & - - - \\
\hline Corophium sp. & - - - & 0.9 & - - - & 0.3 & - . - & - . - & 3.6 & - - - & - - - & - . - \\
\hline Gammarus sp. & - . - & 1.9 & 6.7 & 0.6 & 0.1 & - . - & 2.4 & 3.7 & - . - & - . - \\
\hline Amphipoda n.i. & 2.5 & 7.4 & 26.7 & 4.5 & 0.1 & 2.6 & 24.1 & 6.2 & $-\ldots$ & -- \\
\hline \multicolumn{11}{|l|}{ Small pelagic crustacea } \\
\hline Gastrosaccus sp. & - - - & - - - & 3.3 & 0.3 & 0.1 & - - - & $\ldots$ & $-\ldots$ & $\ldots$ & - - - \\
\hline Neomysis sp. & - - - & - - & $-\ldots$ & 0.3 & 0.3 & - . & - . & - . - & - . & - - - \\
\hline Praunus sp. & 0.8 & - - - & - - & 0.6 & $-\ldots$ & $-\ldots$ & $-\ldots$ & - . - & . - - & - . - \\
\hline Paramysis sp. & $\ldots$ & $\ldots$ & $\ldots$ & - - - & 0.1 & $\ldots$ & $\ldots$ & $\ldots$ & . - - & $\ldots$ \\
\hline Mysidacea n.i. & 6.6 & 6.5 & 36.7 & 8.7 & 0.6 & 3.9 & $-\ldots$ & 12.3 & $-\ldots$ & -- \\
\hline \multicolumn{11}{|l|}{ Macrocrustacea } \\
\hline $\begin{array}{lll}0.8 & 0.9\end{array}$ & & 13.3 & 1.1 & & - . - & & - - - & & 0.3 & \\
\hline Carcinus sp. & - . - & $-\ldots$ & 3.3 & - . - & - . - & - . - & - . - & 12.8 & $\ldots$ & - . - \\
\hline Decapoda n.i. & $\ldots$ & $\ldots$ & 6.7 & 0.6 & - . & 0.7 & 1.2 & 3.7 & . - - & $\ldots$ \\
\hline Crustacea n.i. & 12.4 & 13.9 & 13.3 & 13.8 & 0.6 & 4.6 & 7.2 & 6.2 & 0.6 & . - - \\
\hline Algae & 8.3 & 1.9 & 3.3 & 6.5 & 8.1 & 1.3 & $\ldots$ & 12.3 & 13.9 & 9.2 \\
\hline Detritus & 4.1 & 38.9 & $-\ldots$ & 4.5 & 75.1 & 54.6 & 4.8 & 2.5 & 91.2 & 95.7 \\
\hline Eggs n.i. & 5.4 & - - - & - . - & 5.3 & 0.1 & $\ldots$ & $\ldots$ & 1.2 & 0.3 & 0.7 \\
\hline Fish & -- & 5.6 & 3.3 & $-\cdots$ & 1.1 & 1.3 & 4.8 & 3.7 & 0.6 & - - \\
\hline Size length (cm TL) & $2-12$ & $1-9$ & $3-20$ & $5-15$ & $2-27$ & $4-16$ & $4-16$ & $6-63$ & $2-31$ & $2-120$ \\
\hline No. Non-empty stomachs & 246 & 108 & 30 & 355 & 972 & 114 & 46 & 39 & 317 & 141 \\
\hline
\end{tabular}

gen positively influenced the abundance and biomass of D. labrax and in the second year, when the oxygen was lower, negatively influenced the distribution of D. labrax and S. pilchardus (Tables 2 and
3). The $\mathrm{pH}$ was positively correlated to the distribution (abundance and biomass) of S. bailloni and A. anguilla in the first year, but when the $\mathrm{pH}$ increased in the second year, the $\mathrm{pH}$ was only positively cor- 


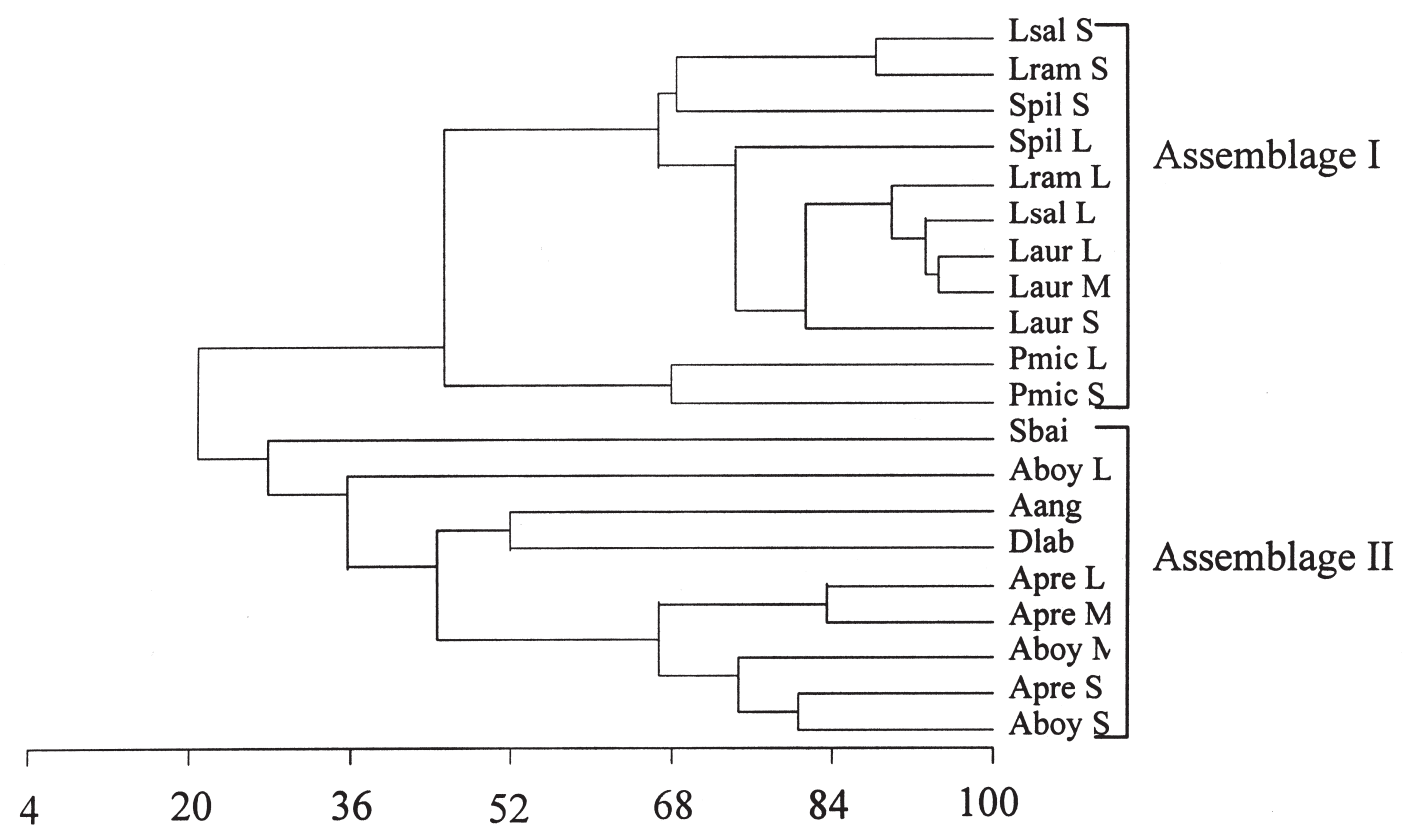

FIG. 9. - Bray-Curtis similarity of frequency of occurrence of stomach contents of fish during 1999. Species code names are provided in Table 1. Size range and number of non-empty stomachs are provided in Table 5. S- small, M- medium, L- large.

related to $P$. microps and negatively correlated to $L$. saliens (Tables 2 and 3 ).

\section{Feeding habits}

The prey frequency of occurrence indicated that several feeding groups are present in fish species (Table 4). The main food items of five species ( $L$. saliens, $L$. ramada, L. aurata, S. pilchardus, and $P$. microps) were detritus. Annelida n.i. and Sphaero$m a$ sp. (Isopoda) were the most representative food items for both Atherinids; all the other categories were occasional prey, i.e. prey were rarely consumed by a large number of individuals. Amphipoda n.i. and Idotea sp. were the most important prey for S. bailloni, and algae, mysidacea n.i. and polychaeta were the most important prey for A. anguilla. D. labrax showed several important food items (mysidacea n.i., polychaeta, amphipoda n.i., and Sphaeroma sp.) although the species can feed opportunistically on other organisms (Table 4).

Classification of samples by cluster analysis of fish food preference identified several assemblages that shared a number of common key prey (Fig. 9).

Cluster analysis distinguished two main groups at the 25\% level of Bray-Curtis similarity (Fig. 9). Assemblage I included all the fish whose diet was strongly dominated by detritus (L. saliens, L. ramada, L. aurata, S. pilchardus, and P. microps) and assemblage II included fish with more than one dominant prey (A. boyeri, A. presbyter, A. anguilla., D. labrax and S. bailloni) (Fig. 9).

Considering assemblage I, small individuals of mullets (L. saliens and L. ramada) (less than $12 \mathrm{~cm}$ ) and $S$. pilchardus (less than $7 \mathrm{~cm}$ ) were classed together at $69 \%$ similarity, showing a preference for copepods, detritus and algae. The second group, including all the sizes of L. aurata and large sizes of the other two mullets (more than $12 \mathrm{~cm}$ ) and $S$. pilchardus (more than $7 \mathrm{~cm}$ ) also showed similarities in diet (74\% similarity), feeding largely on detritus and occasionally on other prey. Large and small $P$. microps, classed together at $68 \%$ similarity, showed a preference for microcrustaceans (cumaceans) and small crustaceans (mysidacea and Sphaeroma sp.) besides detritus.

Considering assemblage II, the two atherinid species were classed together at $67 \%$ similarity (Fig. 9). The diet of smaller individuals (less than $8 \mathrm{~cm}$ ), which included A. presbyter $\mathrm{S}$ and $A$. boyeri $\mathrm{S}$ and $\mathrm{M}$ (Table 5), was based on small benthic crustaceans, especially Sphaeroma sp. Larger individuals (more than $8 \mathrm{~cm}$ ) of $A$. presbyter classed together at $84 \%$ similarity, fed mainly on annelids, bivalves and crustaceans (Table 4), while larger individuals of $A$. boyeri fed mainly on insects. The diet of $A$. anguilla and D. labrax, classed together at $52 \%$ similarity, was very diverse though mainly based on small benthic and pelagic crustaceans, especially mysids, amphipods and Sphaeroma sp. 
TABLE 5. - The size range (cm TL) and the number of non-empty stomachs analysed, between parentheses, for each species. Length groups were established according to size length of species. The length groups with less than 30 stomachs were not considered for the analyses of inter- and intraspecific competition.

\begin{tabular}{|c|c|c|c|c|c|c|c|}
\hline $\begin{array}{l}\text { Size range }(\mathrm{cm} \text { TL) } \\
\text { (No. non-empty stomachs) }\end{array}$ & Aboy & Pmic & Apre & Laur & Spil & Lram & Lsal \\
\hline $\begin{array}{l}\text { Small (S) } \\
\text { Medium (M) }\end{array}$ & $\begin{array}{l}<6(64) \\
6-8(142)\end{array}$ & $<4(52)$ & $\begin{array}{c}<8(78) \\
8-11(157)\end{array}$ & $\begin{array}{c}<10(351) \\
10-13(355)\end{array}$ & $<7(65)$ & $<12(164)$ & $<12(83)$ \\
\hline Large (L) & $>8(40)$ & $\geq 4(56)$ & $>11(108)$ & $>13(266)$ & $\geq 7$ (49) & $\geq 12(153)$ & $\geq 12(58)$ \\
\hline
\end{tabular}

Finally, S. bailloni, showing a different diet and preferring small benthic crustaceans, such as amphipoda n.i. and Idotea sp., was classed together with the other species at $27 \%$ similarity.

\section{DISCUSSION}

Both fish abundance and species diversity can provide managers with a good indication of the health of a particular system (Whitfield, 1996). The estuarine coastal lagoon, Ria de Aveiro, is highly influenced by the adjacent abiotic variations, which affect the recruitment, distribution and the survival of fish species. Most fish found in estuaries and coastal lagoons use these areas for feeding and growth, since they provide protection from predators and ensure high food availability for a number of marine species and juvenile teleosts (Kuo et al., 2001).

In the present study, most fish abundance and biomass changed significantly between sites, showing a preference for some specific areas with particular environmental characteristics. The abiotic factors analysed here greatly influenced fish assemblages but could not fully explain differences between assemblages, as it is difficult to analyse each abiotic factor individually as they interact with each other. Other factors such as the influence of tides, velocity and streams and also the human impacts (Marshall and Elliott, 1996, 1998) probably have a great importance on fish abundance and biomass distribution. The aggregation of lagoon-opportunistic and lagoon-dependent species to restricted areas may make the populations more vulnerable to a number of environmental and human perturbations such as point-source pollution (organic and chemical spills), toxic algal blooms or heavy fishing intensity (Jones et al., 1996).

Temperature was found to be the most important abiotic factor affecting the abundance distribution of fish assemblage, proving to be the best predictor of total abundance, which is more related to fish movements from the sea to the lagoon (and vice-versa) than to migration within the lagoon. Similar results were observed in various regions (Jones et al., 1996; Marshall and Elliott, 1998; Kuo et al., 2001). Water temperature influenced the fish fauna of the lagoon during both spring-summer and autumn-winter, but in opposite ways. For the warmer spring-summer period, with average temperatures higher than $15^{\circ} \mathrm{C}$, fish abundance and biomass were high in the whole lagoon. On the other hand, during the cooler autumn-winter period, the water temperatures at all sites were above average and most of the species markedly decreased in abundance and occurred at the areas near the mouth of the lagoon, especially $A$. anguilla, S. pilchardus and D. labrax, which were positively correlated to temperature.

Salinity significantly varied seasonally and spatially between 0 and 35 , with higher salinities at the entrance, inner and mid-parts of the lagoon during warmer months and with lower salinities near the major river inflows during winter. The seasonal variation of salinity in the whole lagoon was highly related to rainfall. At times of maximum freshwater discharge resulting from rainy periods, as occurred in spring 2000 , the salinity severely decreased all over the lagoon. However, the occurrence of some species throughout the lagoon, such as A. boyeri and $P$. microps, is typical of resident species, irrespective of salinity, which are highly tolerant of variable environmental conditions (Elliott and Taylor, 1989).

The biomass distributions is affected by the movements of fish within the lagoon, which migrate to deeper regions of the lagoon as a strategy of protection against predators and minimisation of food competition with other fish species (Harley et al., 2001) and also between the sea and the lagoon for reproduction reasons. Thus, salinity was found to be the most important abiotic factor affecting fish biomass, as occurs in the Humber estuary, UK (Marshall and Elliott, 1998), with temperature also having an important influence on fish biomass distribu- 
tion. The abiotic conditions diverged within sites and the low biomass of all fish species observed at Areão (Mira channel) $(8.5 \mathrm{~kg}$ in the first year and $6.1 \mathrm{~kg}$ in the second year) contrast with the high biomass at Carregal (Ovar channel) (16.7 kg in the first year and $11.5 \mathrm{~kg}$ in the second year). While the Mira channel is like a small estuary, the Ovar channel behaves like a semi-enclosed coastal lagoon (Cunha, 1999), with high temperature and salinity levels recorded seasonally in the seagrass areas in the most confined regions.

Over the last few decades, there has been an increasing concern about man's impact on the ecosystem (Van Leeuwen et al., 1994). The marine environment may potentially be affected by a variety of human activities, both direct and indirect, such as coastal engineering works, pollution, eutrophication, fisheries and global warming. In order to analyse the possible influences of human activities, a knowledge of the dynamics of the marine ecosystem is necessary. Several natural and anthropogenic factors may have a direct influence on the environment and on food resources, distribution, growth, survival and behaviour of the fish present (Perez-Ruzafa et al., 1991; Whitfield, 1996). One of the effects of dredging and the enlargement of communication channels with the open sea is the colonisation by new marine species. On the other hand, changes in the sediments may result in a fall in the fishery stocks of some species (Perez-Ruzafa et al., 1991). In Ria de Aveiro, dredging occurred in the previous years, between October 1997 and May 1998 , with records of $1,510,000 \mathrm{~m}^{3}$ of extracted sediment from the main channels (Ovar, Murtosa, and Mira) (JAPA, 1993). This enlarged the tidal-range and the water removal, possibly allowing a large variety of fish species, especially marine adventitious species, to enter the lagoon (Pombo et al., 2002a). After the dredging, channels with a greater depth and therefore a greater potential mobility of the fish in the water column possibly induced the entrance of typically marine species from the adjacent ocean (Pombo et al., 2002a). During the sampling period analysed here, depth significantly decreased, while $\mathrm{pH}$ significantly increased, from the first to the second year. The strong rainfalls in 2000 , and consequently the higher flows of water, led to a deepen areas, transporting sediments from one region to another, changing substantially the lagoon sediments and consequently modifying the distribution of fish fauna (Perez-Ruzafa et al., 1991; Harley et al., 2001).
The dietary analysis enabled a further assessment of biological interactions of fish within the lagoon. While intraspecific comparisons according to size are not possible for all the species, interspecific interactions can be assessed. As the seasonal differences in the distribution of the first group of species are shown by negative relationships with different parameters, potential competition may be avoided by the seasonal separation of estuarine use. As $S$. pilchardus is more abundant in regions near the mouth of the lagoon, so that it can easily go back to the sea, these populations may not be limited by diet, which is highly based on detritus but includes a wide range of other organisms. P. microps, with a wide distribution within the lagoon, a weak correlation to the environmental parameters, and a highly diverse diet, may indicate that food may not limit the abundance of the species.

In the other group of fish, the two atherinid species showed a strong selective spatial distribution with the age and a different importance of each food item (Fernandez-Delgado et al., 1988, Creech, 1992, Leonardos and Sinis, 2000; Pombo et al., 2002b), suggesting that they do not compete for the existing food, which was based on small benthic crustaceans, especially Sphaeroma sp. (Isopoda) for younger individuals, and annelids, bivalves, insects and crustaceans for older individuals. D. labrax and A. anguilla, whose diet was mainly based on small pelagic and benthic crustaceans, and polychaets, did not show overlapping spatial distributions (Pombo et al., 2002c). D. labrax was highly distributed near the main river inflow, while $A$. anguilla had a high preference for the main channel and for the upper reaches of Ovar channel. The extensive sea grass in this channel probably contributed to the extremely high abundance recorded in this area, as it provides an additional source of food and shelter (Nagle, 1968; Nienhuis and Van Ierland, 1978 in Cunha, 1999).

The most productive areas within the lagoon appear to be related to finer sediments (upper reaches of Ovar Channel and middle reaches of Mira Channel) (Cunha, 1999). The high organic content and food availability must be substantial and determinant to the fish abundance observed here. In fact, all the species colonised the north edges of Ovar channel, and most of them colonised the Mira channel, except S. bailloni. This marine adventitious species colonises the lagoon occasionally in few restricted areas, especially at the mouth of the lagoon, as they are opportunistic and feed on a wide 
range of food items, especially amphipods and isopods (Idotea sp.). In fact, amphipods dominated the assemblage of the upper reaches in Ovar channel, whereas mysids were dominant in the lower and middle reaches of the channel and all over the Mira channel (Cunha, 1999). On the whole, mysids were dominant during winter and spring and amphipods during summer and autumn (Cunha, 1999). Isopods represented a large portion of the community in the upper reaches of both channels during all the year (Cunha, 1999).

The relationships between environmental variables, especially temperature and salinity, and the abundance of different species, are partly the result of seasonal migrations into and out of the lagoon and, for resident species, recruitment and mortality within the area. This will serve to obscure some of the trends observed with respect to environmental influences, as biological factors may dominate and occur irrespective of water parameters (Marshall and Elliott, 1996). The most important biological relationships are the competition for food and space and the presence of a stock for recruitment (Marshall and Elliott, 1996).

The increasing abundance of benthic and demersal species over the years in the lagoon (Pombo et $a l ., 2002 \mathrm{a}$ ), and their dependence on the benthic fauna, dictates that hydrodynamics and sediment transport regime, responsible for the distribution of sediment environments, play an outstanding role in structuring the suprabenthic community in Ria de Aveiro (Cunha, 1999). However, in this study of diet, only restricted overlapping of spatial distributions of fish with the food groups are evident. More information is required on the availability of prey organisms in the whole lagoon, and on spatial and temporal diet and feeding habits to be sure of their effective influence on the distribution of fishes within the lagoon.

Ria de Aveiro shows a dynamic and a variable environment with abiotic factors and significant variations, in which most species occur in areas with higher-than-average temperatures and salinities. The nursery function of lagoons (Rogers et al., 1984 in Rakocinski et al., 1996; Elliott and Hemingway, 2002) and, as shown by temperature patterns in the Ria de Aveiro, seasonal changes appear to have greater importance to the fish assemblage than the position within the lagoon. Feeding analysis indicates that the fish species are mostly dependent on detritus, and small benthic and pelagic crustaceans. The low spatial segregation of fish in relation to feeding preference suggests that, in a food-rich lagoon like Ria de Aveiro, the environmental-biological interactions could have a greater effect on fish distribution than biological interactions do.

\section{ACKNOWLEDGEMENTS}

The authors would like to thank the University of Aveiro, the Foundation of Science and Technology and the European Social Fund for their financial support for this study. The authors are also very grateful to all the students who helped in the field and laboratory work.

\section{REFERENCES}

Barrosa, J.O. - 1980. A Ria de Aveiro e a sua influência na economia da região. Recurs. Hidric., 1 (3): 83-96.

Bauchot, M.L. and A. Pras. - 1987. Guía de los peces de mar de España y de Europa. Ediciones Omega, Barcelona.

Blaber, S.J.M. and T.G. Blaber. - 1980. Factors affecting the distribution of juvenile estuarine and inshore fish. J. Fish Biol., 17: 143-162.

Borrego, C., M.M. Cruz and P. Gonçalves. - 1994. Estudo de avaliação da vulnerabilidade da capacidade de recepção das águas costeiras em Portugal. Relatório R 3.2. Meios receptores e suas características: (Be 1) - Ria de Aveiro, Pateira de Fermentelos e Barrinha de Mira. IDAD - Projecto n. 13/94, Aveiro.

Creech, S. - 1992. A multivariate morphometric investigation of Atherina boyeri Risso, 1810 and A. presbyter Cuvier, 1829 (Teleostei: Atherinidae): morphometric evidence in support of the two species. J. Fish Biol., 41: 341-353.

Cunha, M.M.P.R. - 1999. Peracaridan crustacea in Ria de Aveiro (NW Portugal): taxonomic composition and spatio-temporal structure of the assemblages; life history and secondary production of Corophium multisetosum Stock, 1952 (Amphipoda, Corophiidae). Ph. D. thesis, Univ. Aveiro, Portugal.

Duffy-Anderson, J.T. and K.W. Able. - 1999. Effects of municipal piers on the growth of juvenile fishes in the Hudson River estuary: a case across a pier edge. Mar. Biol., 133: 409-418.

Elliott, M and K.L. Hemingway (eds.). - 2002. Fishes in Estuaries. Blackwell Science, Oxford.

Elliott, M. and C.J.L. Taylor. - 1989. The structure and functioning of an estuarine/marine fish community in the Forth estuary, Scotland. In: Polish Academy of Sciences Institute of Oceanology (eds.), Proceedings of the $21^{\text {st }}$ European Marine Biologists Symposium (Gdansk), pp. 227-240. Warsaw.

Elliott, M. and F. Dewailly. - 1995. The structure and components of European estuarine fish assemblages. Neth. J. Aquat. Ecol., 29(3-4): 397-417.

Elliott, M., A.H. Griffiths and C.J.L. Taylor. - 1988. The role of fish studies in estuarine pollution assessment. J. Fish Biol., 33(Supplement A): 51-61.

Fernandez-Delgado, C., J.A. Hernando, M. Herrera and M. Bellido. - 1988. Life history patterns of the sand smelt Atherina boyeri Risso 1810 in the estuary of the Guadalquivir River, Spain. Estuar. Coast. Shelf Sci., 27: 697-706.

Haedrich, R.L. - 1983. Estuarine fishes. In: B. Ketchum (ed.), Estuaries and enclosed Seas, pp. 183-207. Elsevier, Amsterdam.

Hall, A. - 1980. Water quality problems in Ria de Aveiro. A preliminary assessment. In: Seminar on actual problems of oceanography in Portugal, 20-21 November, pp. 159-169. Lisbon.

Harley X., P. Koubbi and A. Grioche. - 2001. Ecology of plaice (Pleuronectes platessa) in fish assemblages of beaches of the Opale coast (North of France) during spring 1977. Cybium, 25(1): 67-80.

Hayward, P.J. and J.S. Ryland. - 1998. Handbook of the Marine 
Fauna of north west. Oxford University press, United States.

Hyslop, E.J. - 1980. Stomach contents analyses - a review of the methods and their application. J. Fish Biol., 17: 411-429.

Irigoien, X., J. Post, J. Castel, K.F. Pfeiffer and B. Hellmann. 1999. Nycthemeral variations of the dissolved oxygen concentration in the turbidity maximum of three European estuaries: biological vs. physical processes. J. Mar. Syst., 22: 173-177.

JAPA. - 1993. Estudo de impacto ambiental - desassoreamento da Ria de Aveiro, $1^{a}$ fase. Junta Autónoma do Porto de Aveiro. Edição do Porto de Aveiro, Aveiro.

Jones, G.K., J.L. Baker, K. Edyvane and G.J. Wright. - 1996 Nearshore fish community of the Port River-Baker Inlet Estuary, South Australia. I. Effect of the thermal effluent on the fish community structure, and distribution and growth of economically important fish species. Mar. Freshwat. Res., 47: 785-99.

Kara, M.H. and F. Derbal. - 1996. Régime alimentaire du Loup Dicentrarchus labrax (Poisson, Moronidé) du Golfe d'Annaba, Algérie. Ann. Inst. Océanogr., 72(2): 185-194.

Kuo, S.-R., H.-J. Lin and K.-T. Shao. - 2001. Seasonal changes in abundance and composition of the fish assemblage in Chiku lagoon, Southwestern Taiwan. Bull. Mar. Sci., 68(1): 85-99.

Leonardos, I. and A. Sinis. - 2000. Age, growth and mortality of Atherina boyeri Risso, 1810 (Pisces: Atherinidae) in the Mesolongi and Etolikon lagoons (W. Greece). Fish. Res., 45: 81-91.

Lima, C. - 1986. Impacto da poluição por mercúrio nos organismos aquáticos da Ria de Aveiro. Relatórios do Instituto Nacional de Investigação das Pescas 66, Aveiro.

Lucas, M.F., M.T. Caldeira, A. Hall, A.C. Duarte and C. Lima. 1986. Distribution of mercury in the sediments and fishes of the lagoon of Aveiro, Portugal. Water Sci. Technol., 18: 141-148.

Marchand, J. - 1993. The influence of seasonal salinity and turbidity maximum variations on the nursery function of the Loire estuary (France). Neth. J. Aquat. Ecol., 27: 427-436.

Marshall, S. and M. Elliott. - 1996. The structure of the fish assemblage in the Humber Estuary, U.K. Publ. Espec. Inst. Esp. Oceanogr., 21: 231-242.

Marshall, S. and M. Elliott. - 1998. Environmental influences on the fish assemblage of the Humber Estuary, U.K. Estuar. Coast. Shelf Sci., 46: 175-184.

Morgado, F.M.R. - 1997. Ecologia da zooplâncton da Ria de Aveiro - Caracterização espácio-temporal, transporte longitudinal e dinâmica tidal, nictemeral e lunar. Ph.D. thesis, Univ. Aveiro, Portugal.

Nagle, J.S. - 1968. Distribution of the epibiota of macroepibenthic plants. Contrib. Mar. Sci., 13: 105-144.

Nienhuis, P.H. and E.T. Van Ierland. 1978. Consumption of eelgrass, Zoostera marina, by birds and invertebrates during the growing season in Lake Grevenlingen (SW Netherlands). Neth. J. Sea Res. 12(2): 180-194.

Perez- Ruzafa, A., C. Marcos-Diego and J.D. Ros. - 1991. Environmental and biological changes related to recent human activities in the Mar Menor (SE of Spain). Mar. Pollut. Bull., 23: $747-751$

Perry, R.I., M. Stocker and J. Fargo. - 1994. Environmental effects on the distribution of groundfish in Hecate Strait, British Columbia. Can. J. Fish. Aquat. Sci., 51: 1401-09.

Pombo, L. and J.E. Rebelo. - 2002. Spatial and temporal organisation of a coastal lagoon fish community - Ria de Aveiro, Portugal. Cybium, 26(3): 185-196.
Pombo, L., M. Elliott and J.E. Rebelo. - 2002 a. Changes in the fish fauna of the Ria de Aveiro estuarine lagoon (Portugal) during the twentieth century. J. Fish Biol., 61(Suppl. A): 167-181.

Pombo, L., C. Dias and J.E. Rebelo. 2002 b. Diet comparison between Atherina boyeri Risso, 1810 and Atherina presbyter Cuvier, 1829 in the Ria de Aveiro, Portugal. Rev. Biol. (Lisboa), 20: 59-72.

Pombo, L., C. Lopes and J.E. Rebelo. 2002 c. A comparison study on the age and growth of Atherina boyeri Risso, 1810 and Atherina presbyter Cuvier, 1829 in the Ria de Aveiro, Portugal. Rev. Biol. (Lisbon), 20: 47-58.

Pomfret, J.R., M. Elliott, M.G. O’Reilly and S. Philips. - 1991. Spatial and temporal patterns in the fish communities in the U.K. North Sea estuaries. In: M. Elliott and J-P. Ducrotoy (eds.), Estuaries and coasts: spatial and temporal intercomparisons, pp. 277-284. Olsen and Olsen, Fredensborg.

Pope, K.L. and D.W. Willis. - 1996. Seasonal influences on freshwater fisheries sampling data. Rev. Fish. Sci., 4(1): 57-73.

Potter, I.C., L.E. Beckley, A.K. Whitfield and R.C.J. Lenanton. 1990. Comparisons between the roles played by estuaries in the life cycles of fishes in temperate Western Australia and Southern Africa. Environ. Biol. Fish., 28: 143-178.

Rakocinski, C.F., J. Lyczkowski-Shultz and S.L. Richardson. 1996. Ichthyoplankton Assemblage structure in Mississippi Sound as revealed by canonical correspondence analysis. Estuar. Coast. Shelf Sci., 43: 237-257.

Rebelo, J.E. - 1992. The ichthyofauna and abiotic hydrological environment of the Ria de Aveiro, Portugal. Estuaries, 15(3): 403-415.

Rebelo, J.E. and L. Pombo. - 2001. Os peixes da Ria de Aveiro. Diversidade, ecologia e distribuição. Câmara Municipal de Aveiro, Aveiro.

Rogers, S.G., T.E. Targett and S.B. Van Sant. - 1984. Fish nursery use in Georgia salt-marsh estuaries: the influence of springtime freshwater conditions. Trans. Am. Fish. Soc., 113: 595-606.

Rosecchi E. AND Y. Nouaze. - 1985. Comparaison de cinq indices alimentaires utilisés dans l'analyse des contenus stomacaux. Ver. Trav. Inst. Pêches Mant., 49(3, 4): 111-123.

Sokal, R.R. and F.J. Rohlf. - 1995. Biometry. W.H. Freeman and company, $3^{\text {rd }}$ ed., New York.

Ter Brack, C. J. F. 1986. Canonical correspondance analysis: A new eigenvector technique for multivariate direct gradient analysis. Ecology, 67: 1167-1179.

Van Leeuwen, P.I., A.D. Rijnsdorp and B. Vingerhoed. - 1994. Variations in abundance and distribution of demersal fish species in the coastal zone of the Southeastern North Sea between 1980 and 1993. Demersal Fish Committee, 10: 1-19.

Whitehead, P.J.P., M.L. Bauchot, J.C. Hureau, J. Nielsen and E. Tortonese. - 1986. Fishes of the North-eastern Atlantic and the Mediterranean. UNESCO, Paris.

Whitfield, A.K. - 1996. Fishes and the environmental status of South African estuaries. Fish. Manage. Ecol., 3: 45-57.

Wootton, R.J. - 1990. Ecology of teleosts fishes. Chapman and Hall, London.

Zar, J.H. - 1984. Biostatistical Analysis. Prentice-Hall, Inc., $2^{\text {nd }}$ ed., New Jersey.

Scient. ed.: M. Harmelin-Vivien 
